\title{
Kesesuaian Penempatan Kerja dan Kompetensi terhadap Prestasi Kerja yang Dimoderasi oleh Tingkat Pendidikan pada Badan Pengelola Pajak dan Retribusi Daerah Kota Medan
}

\author{
Bagus Handoko \\ baguscipta@gmail.com \\ Universitas Harapan Medan \\ M. Fauzan Azhmy \\ fauzanazhmy@gmail.com \\ Universitas Harapan Medan \\ Shahnaz Nabila \\ nshahnaz13@yahoo.co.id \\ Universitas Harapan Medan
}

\begin{abstract}
This study aims to determine the effect of suitability of work placement and compensation on work performance in the Medan City Regional Tax and Retribution Management Agency. To find out whether the level of education moderates the effect of suitability of work placement and competence on work performance in the Medan City Regional Tax and Retribution Management Agency. The population in this study was 175 people, and using slovin obtained a sample of 121 people. The analysis technique used is multiple linear regression and MRA. The results showed that the suitability of work placement had a significant effect on job performance in the Medan City Regional Tax and Retribution Management Agency. Competence does not affect work performance at the Medan City Regional Tax and Retribution Management Agency. The conclusion that can be obtained from the above results is that the moderator is proven to be significant in influencing the suitability of work placement for work performance. The conclusion that can be obtained from the above results is that the moderator is proven to be significant in influencing competence on work performance.
\end{abstract}

Keywords: competency, education level, job performance, job placement suitability

\section{Pendahuluan}

Era reformasi dan dampak persaingan globalisasi dewasa ini menuntut adanya percepatan perubahan perbaikan prestasi kerja pelayanan dari perusahaan baik itu swasta maupun pemerintah. Pegawai dituntut bekerja lebih profesional, transparan dan akuntabilitas dalam mendukung reformasi dan menunjang kelancaran tugas. Setiap organisasi bagaimanapun bentuk dan tujuannya, baik itu organisasi pemerintah maupun swasta, menghendaki agar aktivitas dari usaha-usaha yang dijalankannya dapat terselenggara dengan efektif. Ini berarti bahwa efektivitas kerja merupakan sasaran yang harus dicapai organisasi dalam proses pencapaian tujuan yang telah ditetapkannya.

Seorang karyawan dalam melaksanakan suatu pekerjaan di perusahaan dapat melaksanakan pekerjaannya dengan baik sesuai dengan intruksi pimpinan, tetapi mungkin juga tidak. Oleh karena itu diperlukan adanya motivasi (dorongan) yang datang dari seorang pimpinan terhadap bawahannya dengan jalan melibatkan menyalurkan, dan memelihara prilaku manusia agar bertindak dengan baik. Motivasi biasanya berhubungan erat dengan kesejahteraan dan pada umumnya selalu identik terhadap pemberian bonus dan komisi dalam bentuk upah insentif, fasilitas-fasilitas lain yang diinginkan karyawan tersebut. Dengan motivasi kerja yang tinggi, maka pekerjaan yang sulit akan terasa mudah dilaksanakan, hal ini akan berdampak 
terhadap peningkatan prestasi kerja karyawan tersebut. Hal ini sesuai dengan pendapat Yatipai \& Kaparang (2015) yang menyatakan motivasi berpengaruh signifikan terhadap prestasi kerja karyawan. Hal ini di karenakan motivasi merupakan faktor kuat untuk mendorong semangat atau gairah karyawan untuk melakukan kegiatan tertentu dalam memaksimalkan kinerja dan meningkatkan prestasi kerjanya.

Faktor penempatan pengelola sesuai dengan kompetensi yang dimiliki akan mempengaruhi dari kinerja pengelola itu sendiri. Keberhasilan suatu organisasi sangat dipengaruhi oleh kinerja organisasi. Berbagai cara akan ditempuh oleh lembaga dalam meningkatkan kinerja pengelola, misalnya melalui pendidikan, pelatihan, pemberian kompensasi yang layak, motivasi dan menciptakan lingkungan kerja yang kondusif. Di sisi lain, lembaga dalam meningkatkan kinerja pengelola haruslah mendorong pengelola untuk memiliki kompetensi kerja melalui pelatihan-pelatihan dan dukungan serta mengkondisikan pengelola memiliki kesempatan untuk tumbuh dan berkembang dalam mengantisipasi tantangan dan peluang. Oleh karena itu, lingkungan kerja yang semakin berubah memerlukan perbaikan mengenai tingkat pengetahuan, kemampuan dan kompetensi di tempat kerja (Paulsson, Ivergård, \& Hunt, 2005). Dasar pertimbangan kesesuaian kompetensi pengelola dalam kebijakan penempatan dalam jabatan dan motivasi kerja pengelola sangat menentukan kinerja pengelola. Kompetensi dapat diartikan sebagai kemampuan yang cukup untuk melaksanakan tugas, yaitu meliputi pengetahuan dan keterampilan yang sesuai dengan tuntutan tugas dan tanggung jawabnya.

Penempatan pengelola diharapkan dapat memberikan konstribusi yang memadai bagi organisasi disamping sebagai upaya pengembangan kompetensi sumber daya manusia dalam organisasi. Kesesuaian kompetensi pengelola dengan bidang tugas sangat berpengaruh terhadap kepuasan kerja dan kinerja karyawan. Apabila pengelola menginginkan peningkatan kinerja organisasi, maka kompetensi seseorang karyawan menjadi persyaratan yang utama yang harus dipenuhi dalam penentuan penempatan karyawan. Hal tersebut menunjukkan, bahwa pentingnya kompetensi karyawan dengan bidang tugasnya akan meningkatkan keuntungan kompetitif sebuah organisasi (Cardy \& Selvarajan, 2006).

Faktor kompetensi pengelola yang meliputi kesesuaian pengetahuan dan keterampilan dalam melaksanakan tugas akan memberikan dampak pada kinerja pengelola sebagai perwujudan prestasinya. Semakin tinggi kesesuaian kompetensi seseorang dalam bidang tugasnya akan semakin tinggi tingkat kinerja pengelola. Dapat disimpulkan, bahwa semakin pengelola memiliki kompetensi dan motivasi kerja maka akan semakin tinggi tingkat kinerja pengelola atas prestasi kerja seseorang.

Korossy (2017:54) mengidentifikasi bahwa kompetensi kinerja dalam pengembangan sumber daya manusia terhadap kinerja terdiri dari keahlian (skill), pengetahuan (knowledge), dan kemampuan (ability). Variabel kompetensi keterampilan teknis, kompetensi ketrampilan non teknis, pengetahuan (knowledge) dan kemampuan (ability) mempunyai pengaruh yang signifikan terhadap peningkatan kinerja karyawan. Sedangkan secara parsial variabel yang paling besar memberi pengaruh terhadap prestasi kerja karyawan adalah kompetensi pengetahuan (knowledge). Hal ini menunjukkan pentingnya pengetahuan dan menjalankan pekerjaan sesuai dengan pengetahuan yang dimiliki karyawan, sehingga karyawan mampu menjalankan pekerjaan seefektif dan seefisien mungkin.

Kompetensi mendorong pengelola untuk menerapkan skill dan knowledge yang sesuai kebutuhan pekerjaan. Untuk itu sistem pengembangan sumber daya manusia di perusahaan haruslah berdasarkan kompetensi. Kemampuan sumber daya manusia dalam mengelola sumber-sumber yang ada dalam organisasi sangatlah penting, apabila sumber daya manusia tersebut mempunyai kemampuan tinggi maka organisasi akan dapat berkembang sesuai dengan yang diharapkan, tetapi sebaliknya apabila sumber daya manusia berkemampuan rendah, maka kemungkinan organisasi akan mengalami kegagalan.Kompetensi profesional yang diperoleh melalui pengalaman lapangan dan pembelajaran organisasional dipandang mampu menghasilkan kemampuan bekerja cerdas. Sehingga, karyawan yang berkomitmen pada organisasi akan lebih mau berusaha mencari jalur-jalur alternatif dan lebih mau mencari sarana yang paling cerdas (smart working) untuk mencapai tujuan perusahaan. Berkembangnya Badan 
Pengelola Pajak dan Retribusi Daerah Kota Medan dapat dipahami sebagai fenomena yang cukup menggembirakan, namun hal ini bukan berarti proses perkembangan Badan Pengelola Pajak dan Retribusi Daerah Kota Medan berjalan mulus. Banyak permasalahan yang perlu dicarikan solusi dan penyelesaian seperti promosi jabatan dimana terdapat ketidakadilan disebabkan pimpinan cenderung menggunakan faktor kedekatan atau persaudaraan dalam memberikan jabatan pada seorang karyawan. Kurangnya kemampuan pemahaman pegawai terhadap tugas, ketidakseimbangan pekerjaan terlihat dari jam kerja dimana satu pihak ada yang sibuk dengan pekerjaannya, pihak lain terlihat lebih santai dan masih santai diluar ruangan kantor karena kondisi kerja yang monoton.

Berdasarkan fenomena-fenomena diatas, untuk dapat meningkatkan prestasi kerja karyawan, maka perusahaan perlu mengadakan pelatihan yang lebih baik lagidengan mengikuti perkembangan zaman dan teknologi, agar perusahaan dapat memiliki sumber daya manusia yang lebih berkompeten dalam menjalankan tanggung jawab serta memiliki kinerja yang lebih baik setiap tahunnya sehingga dapat meningkatkan prestasi yang lebih sesuai dengan tujuan perusahaan. Oleh karena itu dalam memecahkan fenomena mengenai menurunnya prestasi kerja karyawan yang disinyalir karena tidak adanya kesesuaian penempatan tenaga kerja dantingkat kompetensi yang kurang.Hal ini dapat diperbaiki dengan peningkatan pelaksanaan pelatihan yang diberikan oleh perusahaan terhadap para karyawan. Maka, dibutuhkan suatu pendekatan perilaku organisasi untuk memecahkan masalah tersebut.

Fenomena yang berkembang dalam perusahaaan untuk meningkatkan prestasi kerjanya adalah keterampilan yang masih kurang memadai, emosi yang kurang stabil, kondisi fisik yang tidak mendukung serta adanya gangguan konflik di dalam keluarga sehingga mempengaruhi pekerjaan karyawan. Penyelesaian yang kurang cepat dari diri karyawan menyebabkan prestasi kerjanya menjadi menurun sehingga berpengaruh terhadap produktivitas kerja karyawan.

\section{Kajian Pustaka}

\subsection{Pengertian Prestasi Kerja Karyawan}

Prestasi kerja karyawan yang tinggi dari setiap karyawan merupakan hal yang sangat diinginkan. Menurut Mangkunegara (2017), prestasi kerja itu dapat di definisikan sebagai“Hasil kerja secara kualitas dan kuantitas yang dicapai oleh seseorang pegawai dalam melaksanakan tugasnya sesuai dengan tanggung jawab yang diberikan kepadanya". Prestasi juga merupakan suatu hasil yang dicapai seseorang setelah ia melakukan suatu kegiatan. Sunyoto (2012) mengatakan bahwa "Prestasi merupakan perwujudan seseorang dalam melaksanakan pekerjaan, dikatakan berprestasi apabila dapat melaksanakan pekerjaan dengan baik, artinya mencapai sasaran dengan standar yang telah ditentukan".

\subsection{Indikator Prestasi Kerja}

Menurut Mangkunegara (2017), prestasi kerja seseorang dapat diukur melalui beberapa tahapan sebagai berikut:

a. Kualitas Kerja.

Berkaitan dengan ketepatan, ketelitian, keterampilan dan kebersihan.

b. Kuantitas Kerja.

Dalam hal ini berkaitan dengan output yang perlu diperhatikan juga, bukan hanya output rutin, tetapi juga seberapa cepat bisa menyelesaikan kerja "ekstra".

c. Dapat tidaknya diandalkan. Mengikuti instruksi, inisiatif, hati-hati dan kerajinan.

d. Sikap.

Sikap terhadap perubahan pegawai lain dan pekerjaan serta kerjasama.

\subsection{Pengertian Penempatan Kerja}

Ardana, dkk (2009), menyatakan bahwa ketepatan dalam menetapkan karyawan dengan kesesuaian bidang dan keahlian menjadi sebuah keharusan dari sebuah perusahaan. Promosi merupakan proses penempatan karyawan sebagai penghargaan atau hadiah atas usaha dan prestasinya di masa lampau dengan memindahkannya ke level yang lebih tinggi dari pekerjaan 
yang sebelumnya. Sedangkan menurut (Sastrohadiwiryo, 2003), penempatan adalah proses pemberian tugas dan pekerjaan kepada tenaga kerja yang lulus seleksi untuk dilaksanakan sesuai ruang lingkup yang telah ditetapkan, serta mampu mempertanggung jawabkan segala resiko dan kemungkinan-kemungkinan yang terjadi atas tugas dan pekerjaan, wewenang serta tanggung jawab.

\subsection{Indikator Penempatan Kerja}

Yuniarsih \& Suwatno (2016) menyatakan indikator-indikator penempatan karyawan antara lain sebagai berikut:

a. Pendidikan

Pendidikan yang harus dimiliki oleh seorang karyawan, pendidikan minimum meliputi pendidikan yang disyaratkan dan pendidikan alternatif.

b. Pengetahuan kerja

Pengetahuan yang harus dimiliki oleh seorang karyawan dengan wajar yaitu pengetahuan kerja ini sebelum ditempatkan dan yang baru diperoleh pada waktu karyawan tersebut bekerja dalam pekerjaan tersebut.

c. Keterampilan kerja

Kecakapan atau keahlian untuk melakukan suatu pekerjaan yang harus diperoleh dalam praktek, keterampilan kerja ini dapat dikelompokkan menjadi tiga kategori yaitu keterampilan mental, keterampilan fisik dan keterampilan sosial.

d. Pengalaman kerja

Pengalaman seorang pegawai untuk melakukan pekerjaan tertentu. Pengalaman kerja dapat menjadi bahan pertimbangan untuk pekerjaan yang harus ditempatkan dan lamanya melakukan pekerjaan.

\subsection{Pengertian Kompetensi}

Menurut Edy (2016), secara harfiah kompetensi berasal dari kata competence yang artinya kecakapan, kemampuan, dan wewenang. Hampir senada dengan pernyataan tersebut, Wibowo (2016) berpendapat bahwa kompetensi adalah kemampuan untuk melaksanakan atau melakukan suatu pekerjaan dan tugas yang dilandasi atas keterampilan dan pengetahuan serta didukung oleh sikap kerja yang dituntut oleh pekerjaan tersebut.

\subsection{Indikator Kompetensi}

Adapun yang menjadi indikator kompetensi sumber daya manusia menurut Edy (2016), yaitu:

a. Pengetahuan (knowledge), yaitu kesadaran dalam bidang kognitif.

b. Pemahaman (understanding), yaitu kedalaman kognitif dan afektif yang dimiliki oleh individu.

c. Kemampuan (skill), adalah sesuatu yang dimiliki oleh individu untuk melaksanakan tugas atau pekerjaan yang dibebankan kepadanya.

d. Nilai (value), adalah suatu standar perilaku yang telah diyakini dan secara psikologis telah menyatu dalam diri seseorang.

e. Sikap (attitude), yaitu perasaan (senang-tidak senang, suka-tidak suka) atau reaksi terhadap rangsangan yang datang dari luar.

f. Minat (interest), adalah kecenderungan seseorang untuk melakukan suatu perbuatan.

\subsection{Pengertian Pendidikan}

Menurut Arza (1988), pendidikan adalah suatu proses dimana suatu bangsa mempersiapkan generasi mudanya untuk menjalankan kehidupan dan memenuhi tujuan kehidupan secara efektif dan efisien. Pendidikan lebih dari sekedar pengajaran, karena dalam kenyataan pendidikan adalah suatu proses dimana suatu bangsa atau negara membina atau mengembangkan kesadaran diri diantara individu-individu, dengan kesadaran tersebut, suatu 
bangsa atau negara dapat mewariskan kekayaan budaya atau pemikiran kepada generasi berikutnya, sehingga menjadi inspirasi bagi mereka dalam setiap aspek kehidupan

\subsection{Indikator Tingkat Pendidikan}

Menurut Pemerintah RI (2003), indikator tingkat pendidikan terdiri dari jenjang pendidikan dan kesesuaian jurusan terdiri dari:

a. Jenjang pendidikan

1) Pendidikan dasar adalah Jenjang pendidikan awal selama 9 (sembilan) tahun pertama masa sekolah anak-anak yang melandasi jenjang pendidikan menengah.

2) Pendidikan menengah adalah Jenjang pendidikan lanjutan pendidikan dasar.

3) Pendidikan tinggi adalah Jenjang pendidikan setelah pendidikan menengah yang mencakup program sarjana, magister, doktor, dan spesialis yang diselenggarakan oleh perguruan tinggi.

b. Kesesuaian jurusan adalah sebelum karyawan direkrut terlebih dahulu perusahaan menganalisis tingkat pendidikan dan kesesuaian jurusan pendidikan karyawan tersebut agar nantinya dapat ditempatkan pada posisi jabatan yang sesuai dengan kualifikasi pendidikannya tersebut. Dengan demikian karyawan dapat memberikan kinerja yang baik bagi perusahaan.

Jenjang pendidikan adalah tahapan pendidikan yang ditetapkan berdasarkan tingkat perkembangan peserta didik, tujuan yang akan dicapai, dan kemampuan yang dikembangkan, terdiri dari:

a. Pendidikan formal indikatornya adalah jenjang pendidikan terakhir yang ditamatkan oleh pekerja, dan kesesuaian jurusan.

b. Pendidikan non formal indikatornya indikatornya relevansi pendidikan nonformal yang pernah diikuti dengan pekerjaan sekarang.

c. Pendidikan informal indikatornya sikap dan kepribadian yang dibentuk dari keluarga dan lingkungan.

\subsection{Hubungan Antar Variabel}

\subsubsection{Hubungan Kesesuaian Penempatan Kerja dengan Prestasi Kerja Karyawan}

Menurut Luthfi (2018), ada pengaruh positif dan signifikan dari variabel penempatan terhadap variabel prestasi kerja karyawan. Hal ini juga didukung oleh pendapat Gentari \& Farhan (2019) yang menyatakan adanya pengaruh penempatan dalam peningkatan Prestasi Kerja Karyawan. Sari \& Ardana (2016) menyatakan bahwa ketepatan dalam menetapkan karyawan dengan kesesuaian bidang dan keahlian menjadi sebuah keharusan dari sebuah perusahaan. Promosi merupakan proses penempatan karyawan sebagai penghargaan atau hadiah atas usaha dan prestasinya di masa lampau dengan memindahkannya ke level yang lebih tinggi dari pekerjaan yang sebelumnya.

$H_{1}$ : Kesesuaian penempatan kerja berpengaruh terhadap prestasi kerja karyawan pada Badan Pengelola Pajak dan Retribusi Daerah Kota Medan

\subsubsection{Hubungan Kompetensi dengan Prestasi Kerja Karyawan}

Widodo (2015) menyatakan bahwa kompetensi berpengaruh signifikan terhadap kinerja, sehingga adanya peningkatan pada kejelasan, keadilan, feedback, dan dampak dari kompetensi akan meningkatkan prestasi kerja karyawan. Kompetensi dapat didefinisikan sebagai proses yang dilakukan oleh organisasi untuk melakukan penilaian atas kinerja yang telah dilaksanakan baik oleh karyawan maupun manajemen (Hasibuan, 2012)

\section{$\mathrm{H}_{2}$ : Kompetensi berpengaruh terhadap prestasi kerja karyawan pada Badan Pengelola} Pajak dan Retribusi Daerah Kota Medan 


\section{Metode Penelitian}

\subsection{Jenis Penelitian}

Penelitian ini merupakan penelitian asosiatif, yaitu penelitian yang bersifat menghubungkan dua variabel atau lebih. Berdasarkan penjelasan di atas, dapat diketahui bahwa penelitian asosiatif yang bermaksud untuk memberikan penjelasan pengaruh kesesuaian penempatan kerja dan kompetensi terhadap prestasi kerja karyawan yang dimoderasi oleh tingkat pendidikan.

\subsection{Teknik Analisis Data Penelitian}

\subsubsection{Persamaan Regresi Linier Berganda}

Untuk mengetahui pengaruh atau hubungan variabel bebas (kesesuaian penempatan kerja dan kompetensi) dengan variabel terikat (prestasi kerja karyawan), maka akan digunakan metode regresi linier berganda dan analisis data juga menggunakan SPSS, rumusnya adalah sebagai berikut:

$$
\mathbf{Y}=\mathbf{a}+\mathbf{b}_{1} \mathbf{X}_{1}+\mathbf{b}_{2} \mathbf{X}_{2}+
$$

\subsubsection{Moderated Regression Analysis (MRA)}

Untuk menguji pengaruh interaksi dari variabel moderasi, pengaruh kesesuaian penempatan kerja dan kompetensi terhadap prestasi kerja karyawan yang dimoderasi oleh tingkat pendidikan menggunakan uji interaksi atau sering disebut dengan Moderated Regression Analysis (MRA). Menurut Ghozali (2019), uji interaksi atau sering disebut dengan Moderated Regression Analysis (MRA) merupakan aplikasi khusus regresi berganda linier dimana dalam persamaan regresinya mengandung unsur interaksi (perkalian dua atau lebih variabel independen). Adapun Moderating Regression Analysis (MRA) dinyatakan dalam dua bentuk persamaan sebagai berikut:

a. MRA I Hipotesis 3

1) Persamaan 2

$$
\mathrm{Z}=\mathrm{a}+\mathrm{b}_{3} \mathrm{X}_{1}+\mathrm{e} 1
$$

2) Persamaan 3

$\mathrm{e}_{\text {absolute }} \quad=\mathrm{a}-\mathrm{b}_{4} \mathrm{Y}$

Keterangan:

$\mathrm{y} \quad=$ Prestasi Kerja Karyawan

a $\quad=$ Konstanta

$\mathrm{b}_{3} \quad=$ Koefisien Regresi Berganda

$\mathrm{X}_{1} \quad=$ Kesesuaian Penempatan Kerja

$\mathrm{Z}=$ Tingkat Pendidikan

$=$ Standard Error

e $_{\text {absolute }}=$ Nilai Absolute Residual

b. MRA I Hipotesis 4

1) Persamaan 2

$$
\mathrm{Z}=\mathrm{a}+\mathrm{b}_{5} \mathrm{X}_{2}+\mathrm{e} 1
$$

2) Persamaan 3

e ebsolute $\quad=a-b_{6} \mathrm{Y}$

Keterangan:

$\mathrm{y} \quad=$ Prestasi Kerja Karyawan

a $\quad=$ Konstanta

$\mathrm{b}_{5} \quad=$ Koefisien Regresi Berganda

$\mathrm{X}_{2} \quad=$ Kompetensi

$\mathrm{Z}=$ Tingkat Pendidikan

$=$ Standard Error

e absolute $_{\text {= Nilai absolute Residual }}$ 
4. Analisis dan Pembahasan

4.1. Analisis Data

4.1.1. Uji Regresi Linier Berganda

Tabel 1. Koefisien Regresi Berganda

\begin{tabular}{|l|r|r|r|r|r|}
\hline \multirow{2}{*}{ Model } & \multicolumn{2}{|c|}{$\begin{array}{c}\text { Unstandardized } \\
\text { Coefisients }\end{array}$} & $\begin{array}{c}\text { Standardized } \\
\text { Coefisients }\end{array}$ & \multirow{2}{*}{ t } & \multirow{2}{*}{ Sig } \\
\cline { 2 - 5 } & \multicolumn{1}{c|}{ B } & Std. Error & Beta & & \\
\hline (Constant) & 7.118 & 1.994 & & 3.569 & .001 \\
Kesesuaian penempatan kerja & .441 & .143 & .361 & 3.071 & .003 \\
Kompetensi & .035 & .108 & .039 & .328 & .744 \\
\hline
\end{tabular}

Sumber : data diolah, 2020.

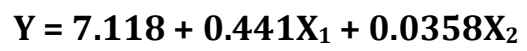

a. Konstanta (a) = 7.118 menunjukkan harga konstan, dimana jika nilai variabel independen tetap, maka prestasi kerja berkurang sebesar 7.118.

b. Koefisien $\mathrm{X}_{1}\left(\mathrm{~b}_{1}\right)=0.441$, menunjukkan bahwa variabel kesesuaian penempatan kerja $\left(\mathrm{X}_{1}\right)$ berpengaruh positif dan signifikan terhadap prestasi kerja $(\mathrm{Y})$ dan akan menambah prestasi kerja sebesar 0.441 .

c. Koefisien $\mathrm{X}_{2}\left(\mathrm{~b}_{2}\right)=0.035$, menunjukkan bahwa variabel kompetensi $\left(\mathrm{X}_{2}\right)$ berpengaruh positif dan signifikan terhadap prestasi kerja $(\mathrm{Y})$, dan akan menambah prestasi kerja sebesar 0.035 .

\subsubsection{Uji F}

Tabel 2. Hasil Uji F

\begin{tabular}{|l|r|r|r|r|r|}
\hline Model & Sum of Squares & \multicolumn{1}{c|}{ d } & Mean Square & F & \multicolumn{1}{c|}{ Sig } \\
\hline Regression & 200.723 & 2 & 100.362 & 10.488 &, 000 \\
Residual & 1129.326 & 118 & 9.571 & & \\
\hline Total & 1330.050 & 120 & & & \\
\hline
\end{tabular}

Sumber : data diolah, 2020 .

Dari hasil uji $F$ di atas, dapat bahwa $F_{\text {hitung }}>F_{\text {tabel }}(10.488>3.09)$ atau sig $F<5 \%(0,000$ $<0,05)$. Berarti secara bersama-sama variabel independen (kesesuaian penempatan kerja dan kompetensi) berpengaruh signifikan terhadap variabel dependen (prestasi kerja).

\subsubsection{Uji t}

Tabel 3. Hasil Uji t

\begin{tabular}{|l|r|r|r|r|r|}
\hline \multirow{2}{*}{ Model } & \multicolumn{2}{|c|}{$\begin{array}{c}\text { Unstandardized } \\
\text { Coefisients }\end{array}$} & $\begin{array}{c}\text { Standardized } \\
\text { Coefisients }\end{array}$ & \multirow{2}{*}{ t } & \multirow{2}{*}{ Sig } \\
\cline { 2 - 4 } & \multicolumn{1}{c|}{ B } & Std. Error & Beta & & \\
\hline (Constant) & 7.118 & 1.994 & & 3.569 & .001 \\
Kesesuaian penempatan kerja & .441 & .143 & .361 & 3.071 & .003 \\
Kompetensi & .035 & .108 & .039 & .328 & .744 \\
\hline
\end{tabular}

Sumber : data diolah, 2020

Nilai t-hitung untuk $X_{1},>$ t-tabel $(3,071>1.980)$, maka kesesuaian penempatan kerja berpengaruh secara signifikan terhadap prestasi kerja.Untuk $\mathrm{X}_{2}$, nilai $\mathrm{t}$-hitung $>\mathrm{t}$-tabel $(0,328<1.980)$, dengan demikian kompetensi tidakberpengaruh secara signifikan terhadap prestasi kerja. 


\subsubsection{Uji Determinasi}

Tabel 4. Koefisien Determinasi

\begin{tabular}{|c|c|c|c|c|}
\hline Model & $\mathbf{R}$ & R Square & Adjusted R Square & Std. Error of the Estimate \\
\hline 1 & .388 & .151 & .137 & 3.09363 \\
\hline
\end{tabular}

Sumber : data diolah, 2020.

Variabel prestasi kerja ( $\mathrm{Y}$ ) dipengaruhi oleh variabel $\mathrm{X}_{1}$ (kesesuaian penempatan kerja) dan variabel $X_{2}$ (kompetensi) secara serentak sebesar 15,1\% dan sisanya sebesar 84,9\% ditentukan oleh variabel lain yang tidak diteliti dalam penelitian ini.

\subsubsection{Hasil Uji MRA}

a. Uji MRA 1 (Uji Hipotesis 4)

1) Uji t

Tabel 5. Hasil Uji t MRA I

\begin{tabular}{|l|r|r|r|r|l|}
\hline \multirow{2}{*}{ Model } & \multicolumn{2}{|c|}{$\begin{array}{c}\text { Unstandardized } \\
\text { Coefisients }\end{array}$} & $\begin{array}{c}\text { Standardized } \\
\text { Coefisients }\end{array}$ & \multirow{2}{*}{ t } & \multirow{2}{*}{ Sig } \\
\cline { 2 - 4 } & \multicolumn{1}{|c|}{ B } & Std. Error & \multicolumn{1}{c|}{ Beta } & & \\
\hline $\begin{array}{l}\text { (Constant) } \\
\text { Kesesuaian penempatan }\end{array}$ & 12.340 & 1.299 & & 9.496 & .000 \\
kerja*Tingkat pendidikan & .716 & .312 & .206 & 2.293 & .024 \\
\hline
\end{tabular}

Dependent Variabel :Prestasi kerja

Sumber : data diolah, 2020.

Hasil uji model parsial (uji t) memperlihatkan bahwa nilai moderasi (kesesuaian penempatan kerja*tingkat pendidikan) memberikan nilai koefisien positif (2.293) dengan sig 0.024. Kesimpulan yang bisa diperoleh dari hasil di atas adalah moderator terbukti signifikan dalam mempengaruhi kesesuaian penempatan kerja terhadap prestasi kerja.

2) Uji F

Tabel 6. Hasil Uji F MRA I

\begin{tabular}{|l|r|r|r|l|l|}
\hline Model & Sum of Squares & \multicolumn{1}{|c|}{ Df } & Mean Square & \multicolumn{1}{l|}{ F } & \multicolumn{1}{c|}{ Sig } \\
\hline Regression & 56.261 & 1 & 56.261 & 5.256 &, 024 \\
Residual & 1273.788 & 119 & 10.704 & & \\
\hline Total & 1330.050 & 120 & & & \\
\hline
\end{tabular}

a. Predictors: (Constant), kesesuaian penempatan kerja_Tingkat pendidikan,

b. Dependent Variabel : Prestasi kerja

Sumber : data diolah, 2020.

Hasil uji signifikansi (uji F) memperlihatkan nilai $\mathrm{F}$ hitung sebesar 5.256 dengan probabilitas $0,024<0,05$. Dengan demikian dapat disimpulkan model ini signifikan dan dapat digunakan untuk memprediksi kesesuaian penempatan kerja melalui tingkat pendidikan terhadap prestasi kerja.

3) Koefisien Determinasi

Tabel 7. Koefisien Determinasi MRA I

\begin{tabular}{|c|c|c|c|c|}
\hline Model & $\mathbf{R}$ & R Square & Adjusted R Square & Std. Error of the Estimate \\
\hline 1 & .206 & .042 & .034 & 3.27171 \\
\hline
\end{tabular}

a. Predictors: (Constant), kesesuaian penempatan kerja_Tingkat pendidikan

b. Dependent Variabel : Prestasi kerja

Sumber : data diolah, 2020. 
Nilai koefisien determinasi pada hasil analisis regresi diketahui nilai koefisien determinasi sebesar 0,206. Nilai Adjusted R Square sebesar 0,042 menunjukkan bahwa kesesuaian penempatan kerja $\left(\mathrm{X}_{1}\right)$ sebagai variabel independent mampu menjelaskan variabel prestasi kerja (Y) melalui tingkat pendidikan di Badan Pengelola Pajak dan Retribusi Daerah Kota Medan sebagai variabel dependent sebesar 4.2\%, sedangkan sisanya sebesar 95.8\% dijelaskan oleh faktor-faktor lain yang tidak dimasukkan dalam penelitian ini.

\section{b. Uji MRA II (Uji Hipotesis 5)}

1) Uji t

Tabel 8. Hasil Uji t MRA II

\begin{tabular}{|l|r|r|r|r|r|}
\hline \multirow{2}{*}{ Model } & \multicolumn{2}{|c|}{$\begin{array}{c}\text { Unstandardized } \\
\text { Coefisients }\end{array}$} & $\begin{array}{c}\text { Standardized } \\
\text { Coefisients }\end{array}$ & \multirow{2}{*}{ t } & \multirow{2}{*}{ Sig } \\
\cline { 2 - 4 } & \multicolumn{1}{|c|}{ B } & Std. Error & Beta & & \\
\hline $\begin{array}{l}\text { (Constant) } \\
\text { Kompetensi*Tingkat }\end{array}$ & 11.768 & 1.357 & & 8.671 & .000 \\
pendidikan & .845 & .322 & .234 & 2.621 & .010 \\
\hline
\end{tabular}

Dependent Variabel :Prestasi kerja

Sumber : data diolah, 2020.

Hasil uji model parsial (uji t) memperlihatkan bahwa nilai moderasi (kompetensi*tingkat pendidikan) memberikan nilai koefisien positif (2.621) dengan sig 0.010. Kesimpulan yang bisa diperoleh dari hasil di atas adalah moderator terbukti signifikan dalam mempengaruhi kompetensi terhadap prestasi kerja.

2) Uji F

Tabel 9. Hasil Uji F MRA II

\begin{tabular}{|l|r|r|r|r|c|}
\hline Model & Sum of Squares & \multicolumn{1}{|c|}{ df } & Mean Square & F & Sig \\
\hline Regression & 72.597 & 1 & 72.597 & 6.871 &, 010 \\
Residual & 1257.452 & 119 & 10.567 & & \\
\hline Total & 1330.050 & 120 & & & \\
\hline
\end{tabular}

a. Predictors: (Constant), Kompetensi_Tingkat pendidikan

b. Dependent Variabel : Prestasi kerja

Sumber : data diolah, 2020.

Hasil uji signifikansi (uji F) memperlihatkan nilai F hitung sebesar 6.871 dengan probabilitas 0,010<0,05. Dengan demikian dapat disimpulkan model ini signifikan dan dapat digunakan untuk memprediksi kompetensi terhadap prestasi kerja melalui tingkat pendidikan.

3) Koefisien Determinasi

Tabel 10. Keofisien Determinasi MRA II

\begin{tabular}{|c|c|c|c|c|}
\hline Model & $\mathbf{R}$ & R Square & $\begin{array}{c}\text { Adjusted } R \\
\text { Square }\end{array}$ & $\begin{array}{c}\text { Std. Error of } \\
\text { the Estimate }\end{array}$ \\
\hline 1 & .234 & .055 & .047 & 3.25067 \\
\hline
\end{tabular}

a. Predictors: (Constant), Kompetensi_Tingkat pendidikan

b. Dependent Variabel : Prestasi kerja

Sumber : data diolah, 2020.

Nilai koefisien determinasi pada hasil analisis regresi diketahui nilai koefisien determinasi sebesar 0,234. Nilai Adjusted $\mathrm{R}$ Square sebesar 0,055 menunjukkan bahwa kompetensi $\left(\mathrm{X}_{2}\right)$ sebagai variabel independent mampu menjelaskan variabel prestasi kerja (Y) melalui tingkat pendidikan di Badan Pengelola Pajak dan Retribusi Daerah Kota Medan sebagai variabel dependent sebesar 5.5\%, sedangkan sisanya sebesar 94.5\% dijelaskan oleh faktorfaktor lain yang tidak dimasukkan dalam penelitian ini. 


\subsection{Pembahasan}

\subsubsection{Pengaruh Kesesuaian Penempatan Kerja dengan Prestasi Kerja Karyawan}

Berdasarkan hasil pengujian statistik diperoleh hasil bahwa kesesuaian penempatan kerja berpengaruh signifikan terhadap semangat kerja karyawan pada Badan Pengelola Pajak dan Retribusi Daerah Kota Medan.Ketepatan dalam menetapkan karyawan dengan kesesuaian bidang dan keahlian menjadi sebuah keharusan dari sebuah perusahaan. Promosi merupakan proses penempatan karyawan sebagai penghargaan atau hadiah atas usaha dan prestasinya di masa lampau dengan memindahkannya ke level yang lebih tinggi dari pekerjaan yang sebelumnya.

Sementara itu dari hasil persentase responden yang dilakukan menunjukkan bahwa sebagian karyawan berpendapat sangat setuju sekitar 42,15 \% - 47,93 \% bahwa pendidikan yang dimiliki oleh seorang karyawan mempengaruhi penempatan kerja, pengetahuan yang harus dimiliki oleh seorang karyawan agar bisa ditempatkan sesuai dengan ilmunya, kecakapan atau keahlian untuk melakukan suatu pekerjaan dan pengalaman seorang karyawan untuk melakukan pekerjaan tertentu di dalam perusahaan sangat membantu karyawan tersebut untuk dapat meningkatkan prestasi kerjanya. Disamping itu, dalam pandangan responden bahwa indikator paling dominan dalam mengukur kesesuaian penempatan kerja dalam diri karyawan dapat dijabarkan sebagai berikut :

a. Pendidikan sebesar $47,93 \%$, ini berarti bahwa pengetahuan yang dimiliki oleh seorang karyawan mempengaruhi penempatan kerja sangat membantunya dalam setiap pekerjaan yang dilakukannya.

b. Pengetahuan kerja sebesar 42,98 \%, ini berarti bahwa karyawan harus memiliki pengetahuan agar bisa ditempatkan perusahaan sesuai dengan ilmunya dan bisa menghasilkan kinerja yang baik.

c. Keterampilan kerja sebesar $42,15 \%$, ini berarti bahwa kecakapan atau keahlian untuk melakukan suatu pekerjaan sangat dibutuhkan suatu keterampilan yang khusus agar bisa memperoleh hasil kerja yang baik juga.

d. Pengalaman kerja sebesar 47,93 \%, ini berarti bahwa seorang karyawan untuk melakukan pekerjaan tertentu membutuhkan pengalaman kerja agar dapat terus meningkatkan potensi dan bakat yang dimilikinya.

Dengan demikian, dapat disimpulkan bahwa pada dasarnya perusahaan menempatkan karyawannya disesuaikan dengan pendidikan, pengetahuan kerjanya, keterampilan kerja dan pengalaman kerja agar dapat menghasilkan suatu kerja yang optimal dan menguntungkan bagi perusahaan. Hasil penelitian ini juga sejalan dengan hasil penelitian yang dilakukan oleh Luthfi (2018) menyebutkan bahwa ada pengaruh positif dan signifikan dari variabel penempatan terhadap variabel prestasi kerja karyawan.

\subsubsection{Pengaruh Kompetensi dengan Prestasi Kerja Karyawan}

Berdasarkan hasil pengujian statistik diperoleh hasil bahwa kompetensi berpengaruh terhadap prestasi kerja pada Badan Pengelola Pajak dan Retribusi Daerah Kota Medan.. Ketepatan dalam menetapkan karyawan dengan kesesuaian bidang dan keahlian menjadi sebuah keharusan dari sebuah perusahaan. Promosi merupakan proses penempatan karyawan sebagai penghargaan atau hadiah atas usaha dan prestasinya di masa lampau dengan memindahkannya ke level yang lebih tinggi dari pekerjaan yang sebelumnya.

Sementara itu dari hasil persentase responden yang dilakukan menunjukkan bahwa sebagian karyawan berpendapat sangat setuju sekitar 39,67 \% - 46,28 \% bahwa saya memiliki pengetahuan dalam bekerja sesuai dengan kebutuhan perusahaan, Saya memahami karakteristik dan kondisi kerja secara efektif dan efisien, saya mampu melaksanakan setiap pekerjaan yang dibebankan dengan baik, perilaku saya dalam melaksanakan tugas sesuai dengan standar perusahaan, sikap saya dalam bekerja dipengaruhi dari luar perusahaan dan saya memiliki minat melakukan suatu pekerjaan sangat membantu karyawan tersebut untuk dapat meningkatkan prestasi kerjanya. Disamping itu, dalam pandangan responden bahwa indikator paling dominan dalam mengukur kompetensi dalam diri karyawan dapat dijabarkan sebagai berikut : 
a. Pengetahuan (knowledge)sebesar 47,93 \%, ini berarti bahwa karyawan memiliki pengetahuan dalam bekerja sesuai dengan kebutuhan perusahaan.

b. Pemahaman (understanding)sebesar $42,98 \%$, ini berarti bahwa karyawan harus memahami karakteristik dan kondisi kerja secara efektif dan efisien.

c. Kemampuan (skill) sebesar $42,15 \%$, ini berarti bahwa karyawan harus mampu melaksanakan setiap pekerjaan yang dibebankan dengan baik.

d. Nilai (value) sebesar 47,93 \%, ini berarti bahwa perilaku dalam melaksanakan tugas sudah sesuai dengan standar perusahaan.

e. Sikap (attitude) sebesar 47,93 \%, ini berarti bahwa sikap karyawan dalam bekerja dipengaruhi dari luar perusahaan

f. Minat (interest) sebesar $47,93 \%$, ini berarti bahwa karyawan memiliki minat melakukan suatu pekerjaan.

Dengan demikian, dapat disimpulkan bahwa pada dasarnya perusahaan menempatkan karyawannya disesuaikan dengan pengetahuan (knowledge),pemahaman (understanding), kemampuan (skill),nilai (value), sikap (attitude) dan minat (interest) dapat menghasilkan suatu kerja yang optimal dan menguntungkan bagi perusahaan. Hasil penelitian ini juga sejalan dengan hasil penelitian yang dilakukan oleh Widodo (2010) menyatakan bahwa kompetensi berpengaruh signifikan terhadap kinerja, sehingga adanya peningkatan pada kejelasan, keadilan, feedback, dan dampak dari kompetensi akan meningkatkan prestasi kerja karyawan.

\section{Kesimpulan dan Rekomendasi}

\subsection{Kesimpulan}

a. Kesesuaianpenempatan kerja berpengaruh signifikan terhadap semangat kerja kary awan pada Badan Pengelola Pajak dan Retribusi Daerah Kota Medan.

b. Kompetensi berpengaruh terhadap prestasi kerja pada Badan Pengelola Pajak dan Retribusi Daerah Kota Medan.

c. Kesimpulan yang bisa diperoleh dari hasil di atas adalah moderator terbukti signifikan dalam mempengaruhi kesesuaian penempatan kerja terhadap prestasi kerja.

d. Kesimpulan yang bisa diperoleh dari hasil di atas adalah moderator terbukti signifikan dalam mempengaruhi kompetensi terhadap prestasi kerja.

\section{2. $\quad$ Rekomendasi}

a. Sebaiknya karyawan mampu menerapkan hasil kerja yang baik mengikuti arahan instruksi yang diberikan oleh pimpinan dalam bekerja serta mengembangkan keahlian dan keterampilan yang dimilikinya agar menjadi disiplin cekatan, serta teliti dalam bekerja.

b. Kompetensi yang diberikan oleh instansi menjadi hal yang cukup penting untuk membentuk tingkat kepercayaan karyawan terhadap instansinya, sehingga instansi diharapkan tetap selalu memberikan dukungan dan peduli terhadap karyawannya.

c. Pihak manajemen agar lebih memperhatikan gairah kerja karyawan karena dilihat dari deskripsi variabel, indikator rasa aman akan membuat pegawai merasa tenang dalam melaksanakan setiap tugas yang diberikan kepadanya. 


\section{Daftar Pustaka}

Ardana, K., Mujiati, N. W., \& Sriathi, A. A. A. (2009). Perilaku Keorganisasian (Edisi Ke-2). Yogyakarta: Graha Ilmu.

Arza, A. (1988). Esei-Esei Intelektual Muslim Dan Pendidikan Islam. Jakarta: Logos Wacana Ilmu.

Cardy, R. L., \& Selvarajan, T. T. (2006). Competencies: Alternative frameworks for competitive $\begin{array}{llll}\text { advantage. } \quad \text { Business } & \text { Horizons, } & \end{array}$ https://doi.org/10.1016/j.bushor.2005.09.004

Edy, S. (2016). Manajemen Sumber Daya Manusia. Jakarta: Kencana.

Gentari, R. E., \& Farhan, A. (2019). Pengaruh Penempatan Kerja dan Pengalaman Kerja Terhadap Prestasi Kerja Karyawan pada Departemen Quality Integration Program di PT. Parkland World Indonesia Cikande-Serang. 5(2), 120-136. Retrieved from https://garuda.ristekbrin.go.id/documents/detail/1619323

Ghozali, I. (2019). Aplikasi Analisis Multivariate dengan Program SPSS. Journal of Chemical Information and Modeling. https://doi.org/10.1017/CB09781107415324.004

Hasibuan, M. S. (2012). Manajemen Sumber Daya Manusia. In Jakarta: PT.Bumi Aksara.

Luthfi, F. (2018). Pengaruh Penempatan dan Keterikatan Karyawan Melalui Motivasi Terhadap Prestasi Kerja (Studi kasus terhadap ASN Polda Riau, Pekanbaru). Jurnal Online Mahasiswa Univeritas Riau, 1(1), 1-15.

Mangkunegara, A. P. (2017). Manajemen Sumber Daya Manusia Perusahaan, Bandung: PT. In Remaja Rosdakarya.

Paulsson, K., Ivergård, T., \& Hunt, B. (2005). Learning at work: competence development or competence-stress. Applied Ergonomics, 36(2), 135-144. https://doi.org/10.1016/j.apergo.2004.09.008

Pemerintah RI. (2003). Undang-Undang Republik Indonesia Nomor 20 Tahun 2003 TeundangUndang Republik Indonesia Nomor 20 Tahun 2003 Tentang Sistem Pendidikan Nasional, Pub. L. No. Bab Ii, Pasal 3, 1 (2003). 1-21. Retrieved from www.hukumonline.com

Sari, A. P., \& Ardana, K. (2016). Peran Mediasi Kepuasan Kerja Pada Pengaruh Kompensasi Terhadap Kinerja Pekerja Kontrak. E-Jurnal Manajemen Universitas Udayana, 5(1),.

Sastrohadiwiryo, S. (2003). Manajemen Tenaga Kerja Indonesia. Jakarta: Bumi Aksara.

Sunyoto, D. (2012). Manajemen Sumber Daya Manusia. Yogyakarta: CAPS.

Wibowo. (2016). Manajemen Kinerja (Edisi Ke-5). Jakarta: Rajawali Pers.

Widodo, S. E. (2015). Manajemen Pengembangan Sumberdaya Manusia (Cetakan Ke). Yogyakarta: Pustaka Pelajar.

Yatipai, T., \& Kaparang, S. G. (2015). Pengaruh Motivasi Terhadap Prestasi Kerja Karyawan Studi Pada PT Pos Indonesia Tipe C Manado. Jurnal Administrasi Bisnis, 3(011), 1-7.

Yuniarsih, T., \& Suwatno. (2016). Manajemen Sumber Daya Manusia: Teori, Aplikasi, dan Isu Penelitian (Cetakan Ke). Bandung: Alfabeta. 